\title{
Schritt für Schritt erklärt
}

\section{Aufklappen - Raustrennen - Mitnehmen}

Die mehrseitige Anleitung zeigt „step-by-step“ interssante Techniken.

Komplett heraustrennbar ist sie immer zur Hand.

Jeder Schritt ist detailliert beschrieben und anschaulich dargestellt.

So funktioniert's

Folgen Sie den Spuren: Im Innenteil wird jeder Schritt genau erklärt.

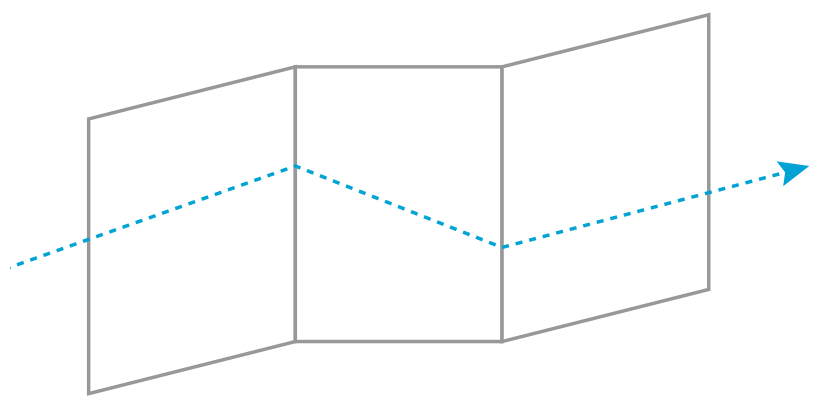

Alles komplett: Außen finden Sie detaillierte Infos zum Behandlungsfall.

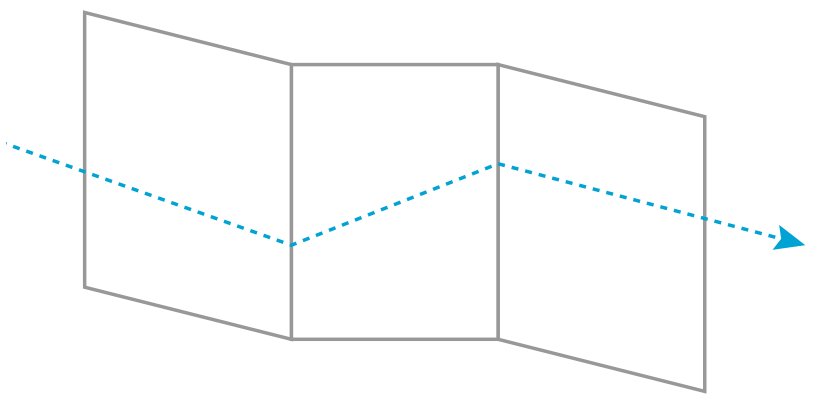

